\title{
Effect of Addition City Garbage As A Nitrogen Source Either Alone or in Combination with Each Nitrate or Urea on Zaghloul and Samany Date Palm Cultivars
}

\author{
Hoda S. H. Aly, M. R. El-Shenawy and M. Badran ${ }^{1}$
}

\begin{abstract}
Field investigation was carried out during 2006/2007and 2007/2008 seasons on Zaghloul and Samany date palm cultivars grown in Alexandria, Egypt to study the effect of different sources of nitrogen namely, city garbage as organic source and urea or ammonium nitrate as chemical sources on yield, fruit quality, and some minerals content on fruits and pinnae, moreover chlorophyll content in pinnae.

Applying $1200 \mathrm{~g} \mathrm{~N} /$ palm/year from city garbage alone or in combination with chemical nitrogen sources improved yield, fruit length and fruit diameter while fruit weight was not affected significantly by the different treatments in both cultivars. TSS and total sugars content were highly when trees fertilized with city garbage in combination with urea for Zaghloul and Samany cultivars. City garbage decreased chlorophyll content in pinnae of Zaghloul and Samany. The highest value was obtained with control $(1200 \mathrm{~g}$ N/palm/year from ammonium sulphate as well as $10 \mathrm{~kg}$ cattle manure) and urea in Zaghloul and Samany, respectively.

Fruit and pinnae mineral content $(\mathrm{N}, \mathrm{P}, \mathrm{K}$ and $\mathrm{Mg}$ ) was not affected significantly by the different treatments in both cultivars. As for the effect of fertilization treatments on fruit heavy metals, in both study seasons the highest value of cadmium in Zaghloul and Samany fruits were recorded when trees treated with combined urea with city garbage. Concerning fruit lead content the highest concentration was obtained with urea and combined urea with city garbage in Zaghloul and Samany, respectively.
\end{abstract}

\section{INTRODUCTION}

The date palm (Phoenix dactylifera $\mathrm{L}$.) is one of the most important members of the family Palmacea which provide a staple food for millions of people in arid and semiarid regions of the world. In Egypt, dates are an economically important crop.

With the present uncertainty in the world food supply and the expected increase in demand, the date palm could be a good source of food of high nutritional value. In fact, date fruit is rich in nutrients, and due to its dietetic values it has always been held in high esteem by people. Furthermore, the date palm is one of the greatest producers of food per hectare, and world date production is well over 3 million tons. The date fruit consists of $70 \%$ carbohydrates (mostly sugars), making it one of the most nourishing natural foods available to man. The water content is between 15 to $30 \%$ depending on the variety and on the maturity stage of the fruit (FAO, 2002).

Application of organic manure minimizes the loss of nutrients by leaching (Balba, 1973). In view of the current world wide shortage of mineral fertilizers and their adverse effect on food production and quality the endeavor to develop efficient techniques of utilizing organic wastes as fertilizers and avoiding the pollution of the environment and fruits caused by using chemical fertilizers as nitrogen sources are urgently needed (Shahein, et al. 2003). Zawadzka et al., (1990) reported that artificial fertilizers contain a high concentration of heavy metals, may present a major source of contamination for soil and vegetables.

The present investigation was carried out to study the effect of using city garbage alone (as organic fertilizer) in combination with nitrogen fertilizers on yield, fruit quality and some fruit and pinnae minerals contents of Zaghloul and Samany date palms.

\section{MATERIALS AND METHODS}

The present investigation was conducted during $2006 / 2007$ and 2007/2008 seasons on mature palm trees (14 years-old) of Zaghloul and Samany date palm cultivars grown in El-Montazah Garden at Alexandria, Egypt. Six fertilization treatments were carried out for each cultivar (Four replicates in each treatment, and two palms for each replicate).

Each palm tree was supplied with $1200 \mathrm{~g} \mathrm{~N}$ in each season from different sources. City garbage as an organic fertilizer was applied at the last week of November in two holes with $70 \mathrm{~cm}$ diameter and $70 \mathrm{~cm}$ depth at a distance of $70 \mathrm{~cm}$ from the palm trunk on two sides in the first season and on the opposite sides in the second season. Control palms received $1200 \mathrm{gm}$ nitrogen from ammonium sulphate and $10 \mathrm{~kg}$ cattle manure as a fertilizer routine for this orchard. Chemical nitrogen fertilizers namely (ammonium nitrate, urea and ammonium sulphate) were added in three equal doses in March, May and July in both experimental seasons. Calcium super phosphate $\left(15.5 \% \quad \mathrm{P}_{2} \mathrm{O}_{5}\right)$ was added at a

\footnotetext{
${ }^{1}$ Hort. Res. Institute, Agric. Center, Egypt.

E-mail: hoda_saad23@yahoo.com

Received March12, 2009, Accepted March30, 2009
} 
rate of $1.5 \mathrm{Kg}$ to each palm once yearly at the same time of addition city garbage. Potassium sulphate $\left(48 \% \mathrm{~K}_{2} \mathrm{O}\right)$ was added at a rate of $(1.5 \mathrm{~kg})$ in two equal doses in March and May. Chemical analysis of city garbage and cattle manure in both seasons was analyzed before used and presented in (Table 1).

Table 1. Analysis of city garbage and cattle manure in 2006 and 2007 seasons

\begin{tabular}{lccccc}
\hline \multicolumn{1}{c}{ Organic source } & $\mathbf{N}$ & $\mathbf{P}$ & $\mathbf{K}$ & $\mathbf{M g}$ & $\mathbf{N a}$ \\
\hline City garbage & 0.92 & 0.39 & 0.29 & 0.68 & 0.43 \\
Cattle manure & 1.89 & 0.73 & 1.01 & 0.93 & 0.32 \\
\hline & \multicolumn{5}{c}{2007} \\
\hline City garbage & 1.05 & 0.43 & 0.38 & 0.59 & 0.37 \\
Cattle manure & 1.72 & 0.79 & 1.07 & 0.89 & 0.31 \\
\hline
\end{tabular}

Fruit quality was determined at harvest date (the end of Khalal stage), fruit weight, fruit length and diameter as physical properties. While chemical properties as total sugars and soluble tannins were determined (\% on fresh weight basis) according to Dubios et al. (1956) and Swain and Hillis (1959), respectively, total soluble solids (TSS \%) was determined in fruit juice by hand referactometer.

For determine of leaf and fruit mineral contents $(\mathrm{N}$, $\mathrm{P}, \mathrm{K}$ and $\mathrm{Mg}$ ) and some heavy metals in fruits $(\mathrm{Pb}$ and Cd) were also done. Twenty pinnae (as a sample) from each experimental palm were collected at mid November in both seasons from the medium part of the five consecutive leaves which less than one year old and located just over the fruiting zone as described by Rizk (1987), while fruit samples were collected at the end of Khalal stage (harvest date at mid of October). Leaf and fruit samples were washed with tap water, and then with distilled water, then were dried at $70{ }^{\circ} \mathrm{C}$ in an air drying oven until constant weight $0.3 \mathrm{gm}$ of the ground dried material of each sample was digested in mixture of $\mathrm{H}_{2} \mathrm{SO}_{4}$ and $\mathrm{H}_{2} \mathrm{O}_{2}$ for mineral analysis, according to the method described by Evenhunis and Dewaard (1980). Total chlorophyll was measured in pinnae by Minlota chlorophyll meter SPAD.

Total nitrogen and phosphorus were determined calorimetrically according to Evenhuis (1976) and Murphy and Riley (1962), respectively. Potassium was determined by Pertracourt PEP1 Flame Photometer. Magnesium, lead and cadmium were determined by Perkin Elmer Atomic Absorption Sepctrophotometer Model $305 \mathrm{~B}$, the concentration were expressed as part per million (on dry weight basis).

Soil samples were taken at $0-30 \mathrm{~cm}, 30-60 \mathrm{~cm}$ and $60-90 \mathrm{~cm}$ from soil surface orchard for chemical analysis of experiments and the data are shown in (Table 2).
The experiment was designed as Randomized Complete Block Designed (RCBD) and the obtained data was statistically analyzed according to Snedecor and Cochran (1990).

\section{RESULTS AND DISCUSSIONS}

\section{Fruit physical properties and yield:}

The data presented in Tables (3 and 4) showed that all fertilization treatments increased yield as compared with control in both seasons for the two date cultivars. Control treatment in both seasons gave the lowest yield for Zaghloul cultivar and the differences found between this treatment and urea or ammonium nitrate combined with city garbage in the first season, and city garbage alone treatment in the second season, all others treatments in between and no significant differences found among them. City garbage alone tend to increase yield Samany in the first season, while, the differences not big enough to be significant in the second season. In Samany cultivar found that city garbage in the first season increase the yield and the differences were statistically significant. In the second season control and ammonium nitrate combined with city garbage decrease the yield and the differences were statistically significant among them either ammonium nitrate or city garbage alone. Increasing yield due to using of city garbage compared with control or other inorganic nitrogen sources may be due to the effect of organic manures in improving soil properties (Abdel-Nasser, G. and M.M.Harhash 2000), increasing in nutrients content also may be explained on the basis that the organic materials increased the soil water holding capacity which encourage the solubility and consequently the available nutrients (Zaid and Kriem, 1992; El-Kassas et al.1997 and Nassar, 1998).

As for the effect of fertilization treatments on fruit weight the data in Tables ( 3 and 4) indicated that the differences in fruit weight of Zaghloul cultivar was not big enough to be significant among all fertilization treatments in both experimental seasons, while in Samany cultivar fruit weight was affected with fertilizers, city garbage alone increased fruit weight than that of city garbage in combination with urea or ammonium nitrate and the differences were statistically significant in the first season, while city garbage alone or in combination with urea increased fruit weight in the second season comparing with control.

City garbage alone in the first season or in combination with ammonium nitrate in the second season increased fruit length than that of urea and city garbage combination with ammonium nitrate in the first season and control in the second season for Zaghloul cultivar, however, in Samany city garbage alone or in 
Table 2. Soil analysis of the experimental orchard

\begin{tabular}{llllllll}
\hline Poil Depth & $\mathbf{p H}$ & $\mathbf{E C ~ d s / m}$ & $\mathbf{N a}^{+} \mathbf{m e q} / \mathbf{L}$ & $\begin{array}{l}\mathbf{C a}^{++} \\
\mathbf{m e q} / \mathbf{L}\end{array}$ & $\begin{array}{l}\mathbf{M g}^{++} \\
\mathbf{m e q} / \mathbf{L}\end{array}$ & $\begin{array}{l}\mathbf{C l}^{-} \\
\mathbf{m e q} / \mathbf{L}\end{array}$ & $\begin{array}{l}\mathbf{K} \\
\mathbf{m e q} / \mathbf{L}\end{array}$ \\
\hline $0-30 \mathrm{Cm}$ & 7.87 & 0.73 & 2.76 & 2.97 & 1.0 & 3.99 & 0.223 \\
$30-60 \mathrm{Cm}$ & 7.92 & 0.42 & 1.14 & 1.74 & 0.6 & 1.49 & 0.157 \\
$60-90 \mathrm{Cm}$ & 7.81 & 0.44 & 1.81 & 1.70 & 1.0 & 2.24 & 0.142 \\
\hline
\end{tabular}

combined with urea in the first season and second season, respectively detected to increase fruit length than that of ammonium nitrate either alone or combined with city garbage and urea combined with city garbage in the first season and urea alone and ammonium nitrate either alone or combined with city garbage in the second seasons and the differences were statistically significant (Tables 3 and 4).
Concerning the fruit diameter, the data in Tables ( 3 and 4) showed that control treatment and urea in combination with city garbage in the first and second seasons, respectively gave the lowest average for fruit diameter in Zaghloul cultivar and the differences were significant between Control and urea combined with city garbage in the first season, and between city garbage alone and the combination of urea and city garbage in the second season. While control, urea alone and city

Table 3. Effect of fertilization treatments on some fruit physical properties and yield for Zaghloul cultivar during 2006/2007 and 2007/2008 seasons

\begin{tabular}{|c|c|c|c|c|}
\hline \multirow{2}{*}{ Treatment } & Yield (kg/palm) & Fruit weight (gm) & Fruit length $(\mathrm{cm})$ & Fruit diameter $(\mathrm{cm})$ \\
\hline & \multicolumn{4}{|c|}{$2006 / 2007$} \\
\hline Control & $94.33 b$ & $25.11 \mathrm{a}$ & $5.72 \mathrm{ab}$ & $2.39 b$ \\
\hline Urea & $109.15 \mathrm{ab}$ & $25.15 \mathrm{a}$ & $5.65 b$ & $2.44 \mathrm{ab}$ \\
\hline Ammonium nitrate & $110.68 \mathrm{ab}$ & $26.10 \mathrm{a}$ & $5.79 \mathrm{ab}$ & $2.48 \mathrm{ab}$ \\
\hline $1 / 2 u+1 / 2$ city & $127.258 \mathrm{a}$ & $26.20 \mathrm{a}$ & $5.74 \mathrm{ab}$ & $2.49 \mathrm{a}$ \\
\hline $1 / 2 A+1 / 2$ city & $123.25 \mathrm{a}$ & $25.03 \mathrm{a}$ & $5.58 \mathrm{~b}$ & $2.44 \mathrm{ab}$ \\
\hline \multirow[t]{2}{*}{ City garbage } & $111.75 \mathrm{ab}$ & $27.65 \mathrm{a}$ & $6.02 \mathrm{a}$ & $2.48 \mathrm{ab}$ \\
\hline & \multicolumn{4}{|c|}{$2007 / 2008$} \\
\hline Control & $123.71 b$ & $30.88 \mathrm{a}$ & $5.95 b$ & $2.78 \mathrm{ab}$ \\
\hline Urea & $135.86 \mathrm{ab}$ & $32.18 \mathrm{a}$ & $6.18 \mathrm{ab}$ & $2.75 \mathrm{ab}$ \\
\hline Ammonium nitrate & $126.38 \mathrm{ab}$ & $34.20 \mathrm{a}$ & $6.13 \mathrm{ab}$ & $2.83 \mathrm{a}$ \\
\hline $1 / 2 u+1 / 2$ city & $128.68 \mathrm{ab}$ & $31.30 \mathrm{a}$ & $6.00 \mathrm{ab}$ & $2.65 b$ \\
\hline $1 / 2 A+1 / 2$ city & $131.37 \mathrm{ab}$ & $33.10 \mathrm{a}$ & $6.28 \mathrm{a}$ & $2.75 \mathrm{ab}$ \\
\hline City garbage & $141.80 \mathrm{a}$ & $33.28 \mathrm{a}$ & $6.13 \mathrm{ab}$ & $2.83 a$ \\
\hline
\end{tabular}

Values with the same letter(s) in each column are not significantly differed at 0.05 leve

Table 4. Effect of fertilization treatments on some fruit physical properties and yield for Samany cultivar during 2006/2007 and 2007/2008 seasons

\begin{tabular}{lcccc}
\hline \multirow{2}{*}{ Treatment } & Fruit weight $(\mathbf{g m})$ & Fruit length $(\mathbf{c m})$ & Fruit diameter $(\mathbf{c m})$ & $\begin{array}{c}\text { Yield } \\
\text { (kg/palm) }\end{array}$ \\
\cline { 2 - 5 } & & & $\mathbf{2 0 0 6 / 2 0 0 7}$ & $104.70 \mathrm{c}$ \\
\hline Control & $28.02 \mathrm{ab}$ & $4.89 \mathrm{ab}$ & $3.02 \mathrm{ab}$ & $118.25 \mathrm{~b}$ \\
Urea & $27.10 \mathrm{ab}$ & $4.79 \mathrm{ab}$ & $2.99 \mathrm{abc}$ & $110.75 \mathrm{bc}$ \\
Ammonium nitrate & $26.85 \mathrm{ab}$ & $4.64 \mathrm{~b}$ & $2.94 \mathrm{bc}$ & $111.25 \mathrm{bc}$ \\
$1 / 2 \mathrm{u}+1 / 2$ city & $26.22 \mathrm{~b}$ & $4.75 \mathrm{~b}$ & $2.87 \mathrm{c}$ & $121.58 \mathrm{~b}$ \\
$1 / 2 \mathrm{~A}+1 / 2$ city & $25.40 \mathrm{~b}$ & $4.74 \mathrm{~b}$ & $2.91 \mathrm{bc}$ & $135.75 \mathrm{a}$ \\
City garbage & $29.98 \mathrm{a}$ & $5.05 \mathrm{a}$ & $3.09 \mathrm{a}$ & $128.20 \mathrm{c}$ \\
\hline & & & $\mathbf{2 0 0 7 / 2 0 0 8}$ & $149.80 \mathrm{abc}$ \\
Control & $29.58 \mathrm{~b}$ & $5.18 \mathrm{abc}$ & $3.03 \mathrm{~b}$ & $168.50 \mathrm{a}$ \\
Urea & $31.48 \mathrm{ab}$ & $5.15 \mathrm{bc}$ & $3.13 \mathrm{ab}$ & $153.20 \mathrm{ab}$ \\
Ammonium nitrate & $30.70 \mathrm{ab}$ & $5.08 \mathrm{c}$ & $3.10 \mathrm{ab}$ & $134.5 \mathrm{bc}$ \\
$1 / 2 \mathrm{u}+1 / 2$ city & $32.95 \mathrm{a}$ & $5.35 \mathrm{a}$ & $3.25 \mathrm{a}$ & $161.30 \mathrm{a}$ \\
\hline City garbage & $30.45 \mathrm{ab}$ & $5.10 \mathrm{c}$ & $3.03 \mathrm{~b}$ & $3.15 \mathrm{ab}$ \\
\hline
\end{tabular}

Values with the same letter(s) in each column are not significantly differed at 0.05 level 
garbage alone gave the highest value in the first season and the differences were be significant between them and urea in combination with city garbage, but control and ammonium nitrate in combination with city garbage in the second season gave the lowest values and the differences were be statistically significant among them and all remaining treatments for Samany cultivar. These findings are in harmony with found by Hussein et al. (1992) and Sourour et al. (1998).

2. Fruit chemical properties and pinnae total chlorophyll:

Effect for fertilization treatments on some chemical properties are listed in Tables (5 and 6) for Zaghloul and Samany fruits. The data showed that total soluble solids were high in control as compared with other treatments for Zaghloul in the first season. For Samany cultivar, the data revealed that, all treatments increased fruit TSS as compared with control in both seasons and the differences were significant in most fertilization treatments. These results are not agreed completely with those found by Bach and Abo-Hassan (1983) they showed that chemical fertilizers plus organic manure decreased the total soluble solids in Khudari fruit as compared with the addition of organic manure only.

As for total sugar, the data in Tables (5 and 6) indicated that city garbage fertilization treatment decreased total sugar for Zaghloul and Samany fruits in both seasons and the differences were statistically significant between this treatment and most of the other treatments. These findings are in line by those found by Aly, Hoda (2003) she found that the palm trees fertilized by town refuse plus urea had a significant

Table 5. Effect of fertilization treatments on some fruit chemical properties and pinnae total chlorophyll ( $\%$ on fresh weight basis) for Zaghloul cultivar during 2006/2007 and 2007/2008 seasons

\begin{tabular}{|c|c|c|c|c|}
\hline \multirow[t]{2}{*}{ Treatment } & TSS & Total sugar & Soluble tannin & Total chlorophyll \\
\hline & \multicolumn{4}{|c|}{$2006 / 2007$} \\
\hline Control & $25.75 \mathrm{a}$ & $34.60 \mathrm{a}$ & $0.099 \mathrm{a}$ & $68.53 a$ \\
\hline Urea & $19.50 \mathrm{c}$ & $32.30 \mathrm{a}$ & $0.081 \mathrm{ab}$ & $66.25 \mathrm{~b}$ \\
\hline Ammonium nitrate & $21.00 \mathrm{bc}$ & $33.00 \mathrm{a}$ & $0.075 b$ & $67.40 \mathrm{ab}$ \\
\hline $1 / 2 u+1 / 2$ city & $23.50 \mathrm{ab}$ & $34.75 \mathrm{a}$ & $0.077 \mathrm{~b}$ & $66.28 \mathrm{~b}$ \\
\hline $1 / 2 A+1 / 2$ city & $20.50 \mathrm{bc}$ & $31.25 \mathrm{ab}$ & $0.084 a b$ & $65.22 \mathrm{bc}$ \\
\hline \multirow{2}{*}{ City garbage } & $18.38 \mathrm{c}$ & $26.40 \mathrm{~b}$ & $0.102 \mathrm{a}$ & $63.75 \mathrm{c}$ \\
\hline & \multicolumn{4}{|c|}{$2007 / 2008$} \\
\hline Control & $22.42 \mathrm{a}$ & $29.60 \mathrm{ab}$ & $0.085 \mathrm{ab}$ & $68.60 \mathrm{a}$ \\
\hline Urea & $19.50 \mathrm{a}$ & $31.24 \mathrm{ab}$ & $0.076 \mathrm{~b}$ & $66.30 \mathrm{abc}$ \\
\hline Ammonium nitrate & $21.00 \mathrm{a}$ & $32.99 \mathrm{a}$ & $0.082 \mathrm{~b}$ & $67.82 \mathrm{ab}$ \\
\hline $1 / 2 u+1 / 2$ city & $22.66 \mathrm{a}$ & $33.52 \mathrm{a}$ & $0.087 \mathrm{ab}$ & $65.40 \mathrm{bc}$ \\
\hline $1 / 2 A+1 / 2$ city & $19.92 \mathrm{a}$ & 29.79ab & $0.092 \mathrm{ab}$ & $64.10 \mathrm{c}$ \\
\hline City garbage & $19.17 \mathrm{a}$ & $26.51 b$ & $0.102 \mathrm{a}$ & $64.28 \mathrm{c}$ \\
\hline
\end{tabular}

higher percentage of total sugars as compared with that fertilized with town refuse alone.

Regarding the effect of fertilization treatments on soluble tannin the data indicated that city garbage in both seasons in addition the control in the first season increased soluble tannin for Zaghloul fruits and the differences were statistically significant among these treatment and some of the other treatments, while in Samany city garbage treatment decreased soluble tannin and the differences were statistically significant between this treatment and (1/2 urea $+1 / 2$ city garbage) treatment, but in the second season no significant difference was found among all treatments. The data of the second season agreed with those found by Mahmoud (2001) who found that there were no significant differences among the studied nitrogen forms for their effects on tannin percentage of Zaghloul and Samany cultivars.

Concerning the total chlorophyll in pinnae the data indicated that control gave the highest value for Zaghloul cultivar, while urea treatment increased total chlorophyll for Samany cultivar in both experimental seasons and the differences were statistically significant among this treatment and most of the other treatments. These different levels of chlorophyll concentration would seem to be correlated with the differences in nitrogen availability between the nitrogen forms in which the treatments. These results coincided with those obtained by Tam and Magistad (1935) who found that the chlorophyll levels in the plots receiving no nitrogen were high in on pineapple plants. 
Values with the same letter(s) in each column are not significantly differed at 0.05 level

Table 6. Effect of fertilization treatments on some fruit chemical properties and pinnae total chlorophyll (\% on fresh weight basis) for Samany cultivar during 2006/2007 and 2007/2008 seasons

\begin{tabular}{|c|c|c|c|c|}
\hline \multirow[t]{2}{*}{ Treatment } & TSS & Total sugar & Soluble tannin & Total chlorophyll \\
\hline & \multicolumn{4}{|c|}{$2006 / 2007$} \\
\hline Control & $20.00 \mathrm{~b}$ & $24.94 d$ & $0.111 \mathrm{ab}$ & $72.93 \mathrm{ab}$ \\
\hline Urea & $24.63 \mathrm{a}$ & $33.65 b$ & $0.123 \mathrm{ab}$ & $76.05 \mathrm{a}$ \\
\hline Ammonium nitrate & $24.38 \mathrm{a}$ & $30.79 b c$ & $0.114 \mathrm{ab}$ & $72.25 b$ \\
\hline $1 / 2 u+1 / 2$ city & $25.0 \mathrm{a}$ & $37.36 \mathrm{a}$ & $0.128 \mathrm{a}$ & $73.65 \mathrm{ab}$ \\
\hline $1 / 2 A+1 / 2$ city & $23.63 \mathrm{a}$ & $30.34 \mathrm{bc}$ & $0.110 \mathrm{ab}$ & $74.18 \mathrm{ab}$ \\
\hline \multirow[t]{2}{*}{ City garbage } & $23.88 \mathrm{a}$ & $29.07 \mathrm{c}$ & $0.102 b$ & $72.63 \mathrm{ab}$ \\
\hline & \multicolumn{4}{|c|}{$2007 / 2008$} \\
\hline Control & $21.00 \mathrm{~b}$ & $26.88 \mathrm{bc}$ & $0.106 \mathrm{a}$ & $73.53 \mathrm{abc}$ \\
\hline Urea & $24.50 \mathrm{a}$ & $35.53 \mathrm{a}$ & $0.108 \mathrm{a}$ & $76.68 \mathrm{a}$ \\
\hline Ammonium nitrate & $22.25 \mathrm{ab}$ & $31.38 \mathrm{ab}$ & $0.106 \mathrm{a}$ & $72.90 \mathrm{bc}$ \\
\hline $1 / 2 u+1 / 2$ city & $24.00 \mathrm{a}$ & $33.53 \mathrm{a}$ & $0.121 \mathrm{a}$ & $73.00 \mathrm{bc}$ \\
\hline $1 / 2 A+1 / 2$ city & $24.00 \mathrm{a}$ & $33.52 \mathrm{a}$ & $0.106 \mathrm{a}$ & $74.80 \mathrm{ab}$ \\
\hline City garbage & $23.00 \mathrm{ab}$ & $25.09 \mathrm{c}$ & $0.102 \mathrm{a}$ & $71.40 \mathrm{c}$ \\
\hline
\end{tabular}

Values with the same letter (s) in each column are not significantly differed at 0.05 level

\section{Fruit minerals content:}

The statistical analysis of the collected data indicated that fertilization types increased nitrogen content in fruits than that of control and the differences were statistically significant among those treatments in both experimental seasons, except urea treamtent in the second season where no significant differences were found between them for Zaghloul cultivar (Tables 7 and 8). In Samany cultivar, ammonium nitrate recorded the heighst value for nitrogen fruit content in the first season and the significant found among it and all other treatments except control and urea treatments, while in the second no significant differences among values associated with all of the field treatments were observed. For the Samany in the first season may be due to that nitrogen is moreavailable to absorb from artificial fertilizers than that from city garbage fertilizers which needs a period for decomposition in soil to become available for the plants.. However, Mikkelsen et al., (1995) stated that organic manure must be mineralized before it can be used by plants. Nitrogen mineralization is a complicated microbial process that is affected by many factors such as soil aeration, temperature, moisture and manure composition.

There were no significant differences among phosphorus values associated with all treatments in the first season for Zaghloul cultivare and in Samany for both experimental seasons. Control treamtent in Zaghloul cultivare recorded the highest value for second season and the differences were statistically significant among this treatment and all other treatments excpet ammonium nitreate combined with city garbage treatment (Tables $7 \& 8$ ). As for Samany cultivar the data indicated that all treatments did not affect fruit phosphorus content in both seasons.. These results agreed with those reported by Basha and Abo-Hassan (1983) and Salem and Mousa (1989b), on Some date palm cultivar, they reported that the flesh content of phosphours not affected by nitrogen applications.

Regarding the effect of fertilization treatments on fruit potassium content the data of the first season indicatetd that control gave the highest value and the differences were statistically significant between this treatment and city garbage for Zaghloul cultivar and $(1 / 2$ urea $+1 / 2$ city garbage) treatment for Samany cultivar, but in the second season for both cultivars there were no significant differences among values produced by all the treatments. The data of the second seasons in both cultivars are in line with those found by Hoda, Aly (2003) who found that there were no significant differences in Samany fruit content of potassium among the different organic and inorganic and combined nitrogen fertilizers.

The data also reveled that, there were no significant differences among values produced by all treatments for fruit magnesium content on Zaghloul cultivar in the first season, while in the second season urea treatment recorded the heighest value and the differences were statisticaly significant between this treatment and city garbage treatment only. Samany cultivar statistical analysis of the first season data showed that control treatment produced a heighest value for fruit magnesium content and the differences were statistically significant among this treatment and all 
other treatments, while in the second season no significant differences were found among all treatments.

Table 7. Effect of fertilization treatments on some minerals content ( $\%$ on dry weight basis) on fruits for Zaghloul cultivar during 2006/2007 and 2007/2008 seasons

\begin{tabular}{|c|c|c|c|c|}
\hline \multirow[t]{2}{*}{ Treatment } & $\mathbf{N}$ & $\mathbf{P}$ & $\mathbf{K}$ & Mg \\
\hline & \multicolumn{4}{|c|}{$2006 / 2007$} \\
\hline Control & $0.52 b$ & $0.097 \mathrm{a}$ & $0.49 a$ & $0.38 \mathrm{a}$ \\
\hline Urea & $0.72 \mathrm{a}$ & $0.090 \mathrm{a}$ & $0.49 \mathrm{ab}$ & $0.38 \mathrm{a}$ \\
\hline Ammonium nitrate & $0.67 \mathrm{a}$ & $0.096 \mathrm{a}$ & $0.47 \mathrm{ab}$ & $0.36 \mathrm{a}$ \\
\hline $1 / 2 u+1 / 2$ city & $0.63 a$ & $0.088 \mathrm{a}$ & $0.46 a b$ & $0.40 \mathrm{a}$ \\
\hline $1 / 2 A+1 / 2$ city & $0.60 \mathrm{a}$ & $0.087 \mathrm{a}$ & $0.46 a b$ & $0.36 \mathrm{a}$ \\
\hline \multirow[t]{2}{*}{ City garbage } & $0.72 \mathrm{a}$ & $0.086 a$ & $0.44 \mathrm{~b}$ & $0.34 \mathrm{a}$ \\
\hline & \multicolumn{4}{|c|}{$2007 / 2008$} \\
\hline Control & $0.41 b$ & $0.103 \mathrm{a}$ & $0.47 \mathrm{a}$ & $0.38 \mathrm{ab}$ \\
\hline Urea & $0.43 \mathrm{ab}$ & $0.090 \mathrm{~b}$ & $0.48 \mathrm{a}$ & $0.39 \mathrm{a}$ \\
\hline Ammonium nitrate & $0.47 \mathrm{a}$ & $0.084 b$ & $0.47 \mathrm{a}$ & $0.35 \mathrm{ab}$ \\
\hline $1 / 2 u+1 / 2$ city & $0.47 \mathrm{a}$ & $0.086 b$ & $0.46 a$ & $0.34 \mathrm{ab}$ \\
\hline $1 / 2 A+1 / 2$ city & $0.47 \mathrm{a}$ & $0.093 \mathrm{ab}$ & $0.46 a$ & $0.34 \mathrm{ab}$ \\
\hline City garbage & $0.47 \mathrm{a}$ & $0.082 \mathrm{~b}$ & $0.45 \mathrm{a}$ & $0.34 \mathrm{~b}$ \\
\hline
\end{tabular}

Values with the same letter(s) in each column are not significantly differed at 0.05 level

Table 8. Effect of fertilization treatments on some minerals (\% on dry weight basis) content on fruits for Samany cultivar during $2006 / 2007$ and 2007/2008 seasons

\begin{tabular}{|c|c|c|c|c|}
\hline \multirow[t]{2}{*}{ Treatment } & $\mathbf{N}$ & $\mathbf{P}$ & $\mathbf{K}$ & Mg \\
\hline & \multicolumn{4}{|c|}{$2006 / 2007$} \\
\hline Control & $0.46 a b$ & $0.115 \mathrm{a}$ & $0.52 \mathrm{a}$ & $0.37 \mathrm{a}$ \\
\hline Urea & $0.46 a b$ & $0.109 \mathrm{a}$ & $0.50 \mathrm{ab}$ & $0.30 \mathrm{~b}$ \\
\hline Ammonium nitrate & $0.49 \mathrm{a}$ & $0.103 \mathrm{a}$ & $0.50 \mathrm{ab}$ & $0.31 b$ \\
\hline $1 / 2 u+1 / 2$ city & $0.44 \mathrm{bc}$ & $0.108 \mathrm{a}$ & $0.49 \mathrm{~b}$ & $0.31 b$ \\
\hline $1 / 2 \mathrm{~A}+1 / 2$ city & $0.40 \mathrm{c}$ & $0.105 \mathrm{a}$ & $0.50 \mathrm{ab}$ & $0.33 b$ \\
\hline \multirow[t]{2}{*}{ City garbage } & $0.42 b c$ & $0.108 \mathrm{a}$ & $0.49 \mathrm{ab}$ & $0.31 b$ \\
\hline & \multicolumn{4}{|c|}{$2007 / 2008$} \\
\hline Control & $0.49 \mathrm{a}$ & $0.102 \mathrm{a}$ & $0.52 \mathrm{a}$ & $0.35 \mathrm{a}$ \\
\hline Urea & $0.55 \mathrm{a}$ & $0.096 \mathrm{a}$ & $0.51 \mathrm{a}$ & $0.30 \mathrm{a}$ \\
\hline Ammonium nitrate & $0.53 \mathrm{a}$ & $0.103 a$ & $0.51 \mathrm{a}$ & $0.34 \mathrm{a}$ \\
\hline $1 / 2 u+1 / 2$ city & $0.50 \mathrm{a}$ & $0.099 \mathrm{a}$ & $0.51 \mathrm{a}$ & $0.30 \mathrm{a}$ \\
\hline $1 / 2 A+1 / 2$ city & $0.49 \mathrm{a}$ & $0.105 \mathrm{a}$ & $0.51 \mathrm{a}$ & $0.37 \mathrm{a}$ \\
\hline City garbage & $0.52 \mathrm{a}$ & $0.099 \mathrm{a}$ & $0.51 \mathrm{a}$ & $0.31 \mathrm{a}$ \\
\hline
\end{tabular}

Values with the same letter(s) in each column are not significantly differed at 0.05 level
4. Pinnae minerals content:
As for the effect of different fertilization treatments on pinnae minerals content the data in Tables (9 and 10) showed that nitrogen content not affected with seasons and Samany cultivar in the second season but in the first season fertilizer with urea alone and city garbage alone gave the highest value for nitrogen comparing with $(1 / 2$ urea $+1 / 2$ city garbage $)$ and the fertilization for Zaghloul cultivar in both experimental

Table 9. Effect of fertilization treatments on some mineral content ( $\%$ on dry weight basis) on pinnae for Zaghloul cultivar during $2006 / 2007$ and $2007 / 2008$ seasons

\begin{tabular}{|c|c|c|c|c|}
\hline \multirow{2}{*}{ Treatment } & $\mathbf{N}$ & $\mathbf{P}$ & $\mathbf{K}$ & Mg \\
\hline & \multicolumn{4}{|c|}{$2006 / 2007$} \\
\hline Control & $0.80 \mathrm{a}$ & $0.160 \mathrm{a}$ & $0.52 \mathrm{a}$ & $0.53 \mathrm{ab}$ \\
\hline Urea & $0.84 a$ & $0.144 b$ & $0.51 \mathrm{a}$ & $0.54 a b$ \\
\hline Ammonium nitrate & $0.69 \mathrm{a}$ & $0.148 \mathrm{ab}$ & $0.52 \mathrm{a}$ & $0.52 \mathrm{~b}$ \\
\hline $1 / 2 u+1 / 2$ city & $0.75 a$ & $0.156 \mathrm{ab}$ & $0.51 \mathrm{a}$ & $0.55 \mathrm{a}$ \\
\hline $1 / 2 \mathrm{~A}+1 / 2$ city & $0.66 \mathrm{a}$ & $0.156 a b$ & $0.49 a$ & $0.53 \mathrm{ab}$ \\
\hline \multirow[t]{2}{*}{ City garbage } & $0.94 \mathrm{a}$ & $0.153 \mathrm{ab}$ & $0.51 \mathrm{a}$ & $0.55 \mathrm{a}$ \\
\hline & \multicolumn{4}{|c|}{$2007 / 2008$} \\
\hline Control & $0.42 \mathrm{a}$ & $0.160 \mathrm{a}$ & $0.52 \mathrm{a}$ & $0.53 \mathrm{ab}$ \\
\hline Urea & $0.48 \mathrm{a}$ & $0.157 \mathrm{a}$ & $0.51 \mathrm{ab}$ & $0.55 \mathrm{a}$ \\
\hline Ammonium nitrate & $0.57 \mathrm{a}$ & $0.151 \mathrm{a}$ & $0.50 \mathrm{~b}$ & $0.52 \mathrm{~b}$ \\
\hline $1 / 2 u+1 / 2$ city & $0.57 \mathrm{a}$ & $0.157 \mathrm{a}$ & $0.50 \mathrm{~b}$ & $0.54 \mathrm{ab}$ \\
\hline $1 / 2 \mathrm{~A}+1 / 2$ city & $0.45 a$ & $0.156 a$ & $0.50 \mathrm{~b}$ & $0.52 \mathrm{~b}$ \\
\hline City garbage & $0.59 a$ & $0.150 \mathrm{a}$ & $0.51 \mathrm{ab}$ & $0.55 \mathrm{a}$ \\
\hline
\end{tabular}


Values with the same letter(s) in each column are not significantly differed at 0.05 levels.

Table 10. Effect of fertilization treatments on some minerals content (\% on dry weight basis) on pinnae for Samany cultivar during 2006/2007 and 2007/2008 seasons

\begin{tabular}{|c|c|c|c|c|}
\hline \multirow[t]{2}{*}{ Treatment } & $\mathbf{N}$ & $\mathbf{P}$ & $\mathbf{K}$ & Mg \\
\hline & \multicolumn{4}{|c|}{$2006 / 2007$} \\
\hline Control & $0.93 \mathrm{ab}$ & $0.120 \mathrm{a}$ & $0.53 a$ & $0.53 \mathrm{a}$ \\
\hline Urea & $1.00 \mathrm{a}$ & $0.114 \mathrm{a}$ & $0.52 \mathrm{a}$ & $0.54 \mathrm{a}$ \\
\hline Ammonium nitrate & $0.88 \mathrm{ab}$ & $0.121 \mathrm{a}$ & $0.51 \mathrm{a}$ & $0.55 \mathrm{a}$ \\
\hline $1 / 2 u+1 / 2$ city & $0.81 \mathrm{~b}$ & $0.122 \mathrm{a}$ & $0.50 \mathrm{a}$ & $0.54 \mathrm{a}$ \\
\hline $1 / 2 \mathrm{~A}+1 / 2$ city & $0.87 \mathrm{ab}$ & $0.117 \mathrm{a}$ & $0.51 \mathrm{a}$ & $0.54 \mathrm{a}$ \\
\hline \multirow[t]{2}{*}{ City garbage } & $0.98 \mathrm{a}$ & $0.124 \mathrm{a}$ & $0.51 \mathrm{a}$ & $0.55 \mathrm{a}$ \\
\hline & \multicolumn{4}{|c|}{$2007 / 2008$} \\
\hline Control & $0.72 \mathrm{a}$ & $0.119 \mathrm{a}$ & $0.52 \mathrm{a}$ & $0.53 a$ \\
\hline Urea & $0.73 a$ & $0.125 \mathrm{a}$ & $0.52 \mathrm{a}$ & $0.53 \mathrm{a}$ \\
\hline Ammonium nitrate & $0.72 \mathrm{a}$ & $0.125 \mathrm{a}$ & $0.49 b c$ & $0.54 \mathrm{a}$ \\
\hline $1 / 2 u+1 / 2$ city & $0.76 a$ & $0.125 \mathrm{a}$ & $0.49 b$ & $0.55 \mathrm{a}$ \\
\hline $1 / 2 \mathrm{~A}+1 / 2$ city & $0.89 a$ & $0.119 \mathrm{a}$ & $0.51 \mathrm{ab}$ & $0.54 \mathrm{a}$ \\
\hline City garbage & $0.71 \mathrm{a}$ & $0.115 \mathrm{a}$ & $0.46 \mathrm{c}$ & $0.55 \mathrm{a}$ \\
\hline
\end{tabular}

Values with the same letter(s) in each column are not significantly differed at 0.05 level

differences were statistically significant. These results are in agreement with those of Harhash and AbdelNasser (2000) who reported that the increase of petiole nitrogen content of flame seedless grapevines as a result of inorganic fertilization alone may be due to the higher uptake of nutrients under such conditions.

Concerning for the phosphorus content no significant differences were found for Zaghloul cultivar in the second season and Samany cultivar in both seasons. Control gave the highest value of phosphorus for Zaghloul cultivar in the first season comparing with urea treatment and the differences were statistically significant. These results in Zaghloul cultivar may be due to the stimulation effect of $\mathrm{NH}_{4}$ cation in intake of some anions such as phosphate as shown by Neilsen and McDonald (1978).

All treatments not affect potassium content for both cultivars in the first season only but in the second season control for Zaghloul and control and urea in Samany gave high value and the differences were significant with most remaining treatments. These results agreed with those obtained by Hoda, Aly (2003) she reported that pinnae content of potassium tend to be higher in urea treatment than that of other treatments. Regarding the magnesium content, no constant trend were appeared for Zaghloul cultivar and the differences were significant for most treatments, but for Samany cultivar no significant differences were found in both seasons.

Table 11. Effect of fertilization treatments on some heavy metals (ppm on dry weight basis) on fruits for Zaghloul and Samany cultivars during 2006/2007 and 2007/2008 seasons

\begin{tabular}{|c|c|c|c|c|}
\hline \multirow[t]{3}{*}{ Treatment } & $\mathbf{P b}$ & Cd & $\mathbf{P b}$ & Cd \\
\hline & \multicolumn{2}{|c|}{$2006 / 2007$} & \multicolumn{2}{|c|}{$2007 / 2008$} \\
\hline & \multicolumn{4}{|c|}{ Zaghloul } \\
\hline Control & $0.67 b c$ & $0.051 \mathrm{~b}$ & $0.79 b c$ & $0.035 \mathrm{~b}$ \\
\hline Urea & $0.87 \mathrm{a}$ & $0.041 \mathrm{c}$ & $0.93 \mathrm{a}$ & $0.035 \mathrm{~b}$ \\
\hline Ammonium nitrate & $0.78 \mathrm{abc}$ & $0.0 .31 \mathrm{~d}$ & $0.92 \mathrm{a}$ & $0.040 \mathrm{~b}$ \\
\hline $1 / 2 u+1 / 2$ city & $0.68 b c$ & $0.061 \mathrm{a}$ & $0.85 \mathrm{~b}$ & $0.050 a$ \\
\hline $1 / 2 A+1 / 2$ city & $0.60 \mathrm{c}$ & $0.044 c$ & $0.77 \mathrm{c}$ & $0.040 \mathrm{~b}$ \\
\hline \multirow[t]{2}{*}{ City garbage } & $0.67 \mathrm{c}$ & $0.047 \mathrm{bc}$ & $0.67 \mathrm{~d}$ & $0.040 \mathrm{~b}$ \\
\hline & \multicolumn{4}{|c|}{ Samany } \\
\hline Control & $0.82 \mathrm{c}$ & $0.050 \mathrm{bc}$ & $0.86 a$ & $0.040 \mathrm{c}$ \\
\hline Urea & $0.86 b c$ & $0.045 \mathrm{~cd}$ & $0.87 \mathrm{a}$ & $0.050 \mathrm{a}$ \\
\hline Ammonium nitrate & $0.84 b c$ & $0.048 \mathrm{c}$ & $0.84 \mathrm{a}$ & $0.043 b c$ \\
\hline $1 / 2 u+1 / 2$ city & $0.93 \mathrm{a}$ & $0.060 \mathrm{a}$ & $0.92 \mathrm{a}$ & $0.050 \mathrm{a}$ \\
\hline $1 / 2 A+1 / 2$ city & $0.90 \mathrm{ab}$ & $0.055 \mathrm{ab}$ & $1.03 \mathrm{a}$ & $0.047 \mathrm{ab}$ \\
\hline City garbage & $0.88 \mathrm{ab}$ & $0.040 \mathrm{~d}$ & $0.89 a$ & $0.048 \mathrm{ab}$ \\
\hline
\end{tabular}


Values with the same letter(s) in each column are not significantly differed at 0.05 levels

\section{Fruit heavy metals:}

The fruit heavy metals trait was significantly affected by fertilization treatments in both study seasons. The highest values were recorded for lead when trees treated with urea and ammonium nitrate alone in both seasons and the differences were statistically significant combined with all other treatments in second season for Zaghloul cultivar. However, in Samany the highest value were recorded in city garbage treatment alone or combined with urea or ammonium nitrate and the differences were statistically significant when compared with control only in the first season, while in the second one did not vary significantly for all treatments (Table 11). The presentd values of fruit lead ranged from 0.60 to $1.03 \mathrm{ppm}$ for Zaghloul and Samany, respectively, these values are lower than those found by Abou Sayed et al., (1997) in Prickly pear fruits (1.55 to $3.32 \mathrm{ppm})$. Radwan and Salama (2006) showed that the highest concentrations of lead were noticed in strawberries followed by peach, melon and date

The data listed in Table (11) revealed that fruit of Zaghloul cultivar, had a significant higher concentration of cadmium when treated with urea combined with city garbage in both seasons than those of all other treatments. For Samany cultivar high cadmium contents were obtained with palms treated with urea combined with city garbage and ammonium nitrate when combined with city garbage in both seasons, urea alone and city garbage alone in the second season only. The above mentioned data partilly agreed with those respected with Aly, Hoda (2003) who mentioned that palm trees fertilized with cattle manure combined with urea had significantly higher fruit cadmium contnets.

\section{CONCLUSION}

It can be concluded that applying $1200 \mathrm{~g}$ $\mathrm{N} /$ palm/year from city garbage alone or in combination with chemical nitrogen sources increased the yield and improved fruit quality. However urea when combined with city garbage increased cadmium and lead in fruits of Zaghloul and Samany cultivars.

\section{REFERENCES}

Abdel-Nasser, G. and M.M. Harhash (2000). Effect of organic farming in combination with elemental sulphur on soil physical and chemical characteristics, yield, fruit quality, leaf water contents and nutritional status of Flame seedless grapevines I. Soil physical and chemical characteristics. J. of Agric. Sci., Mansoura Univ. 25(4), 3541-3558.
Abou Sayed-Ahmed, T.A.; E.A. Abd El-Bary; R.A. AlAshkar (1997). Effect of different sources of irrigation water on soil and prickly pear fruit properties. Proc. of The First Scientific Conf. of Agric. Sci., Fac. of Agric., Assiut Univ., Egypt.

Bacha, M.A. and A.A. Abo-Hassan (1983). Effects of soil fertilization on yield, fruit quality and mineral content of Khudari date palm variety. In Proceeding of the first Symposium on the Date Palm in Saudi Arabia. Al Hassa Saudi Arabia: King Faisal Univ. 174-180.

Balba, A. (1973). Organic and inorganic fertilization of sandy soils. FAO soils Bull., No. 32 sandy soils 23-46, Rome.

Dubios, M.; K.A. Gilles; J.K. Hamitton; P.A. Robers and F. Smith (1956). Colorimetric method for determination of sugars and related substances. Anal. Chem. 28(3): 350356.

El-Kassas, H.I.; A.F. Abou-Hadid and N.M.H. Eissa (1997). Effect of different organic manures on the yield and elemental composition of sweet pepper plants grown on sandy soil. Egypt. J. Appl. Sci. 12(3): 262-281.

Evenhuis, B. (1976). Nitrogen determination. Dept. Agric. Res. Royal Tropical Inst., Amsterdam.

Evenhuis, B. and Dewaard, P.W. (1980). Principles and practices in plant analysis. FAO soils Bull. 39(1): 152162.

FAO (2002). Food and Agricultural Organization of the United Nations Rome.

Harhash, M.M. and G. Abdel-Nasser (2000). Effect of organic manure in combination with elemental sulphur on soil physical and chemical characteristics, yield, fruit quality, leaf water contents and nutritional status of flame seedless gravines. II. Yield, fruit quality, leaf water contents and nutrional status. J. Agric. Sci. Manusoura Univ., 25(6): 2819-2837.

Hoda, S.H. Aly (2003). Nutritional status, yield, fruit quality and fruit nitrate, nitrite and some heavy metals contents of Zaghloul and Samany date palm cultivars in relation to fertilizing with different organic and inorganic nitrogen sourcs. Ph.D. Thesis, Agric. Univ. Alex., Egypt.

Hussein, M.A.; S.Z. El-Agamy; Kamelia, I.A. Amen and S. Galal (1992). Effect of certain fertilization and thinning applications on the yield and fruit quality of Zaghloul date palm. Assiut. J. Agric. Sci. 23(2): 349-360.

Mahmoud, R.I.S. (2001). Effect of different forms and levels of nitrogen fertilization on growth, yield, nutrition status and fruit quality of Zaghloul and Samany date palms. Ph.D. Alex. Univ., Fac. of Agric., Alexandria, Egypt.

Mikkelsen, R.I.; J.P. Zublena and S.A. Molloy (1995). Seasonal effects on nitrogen mineralization from organic wastes added to soil. Proceedings of the $7^{\text {th }}$ Int. Symp. On Agricultural Engineers Puplication. P. 162-169. 
Murphy and Riley (1962). A modified single solution method for the determination of phosphorus in natural waters. Anal. Chem. Acta 27: 31-36.

Nassar, I.N. (1998). Utilization of the municipal Garbage (MG). As a soil Amendment Alex. J. Agric. Res. 43(3): 317-332.

Neilsen, D.R. and J.G. McDonald (1978). Nitrogen in the environment Vol.II. Soil-Plant-Nitrogen relation ships. A subsidiary of Harcourt Brace Jovanvich, Publishers.

Radwan, M. and Salama, A. 2006. Market basket survey for some heavy metals in Egyptian fruits and vegetables. Food and Chemical Toxicology 44: 1273-1278.

Rizk,S.A.Y. (1987). Studied on the effect of fertilization on date palm production. Ph.D. Thesis. Fac. Agric., Ain Shams Univ., Egypt.

Salem, M.S.B. and I.A. Mousa (1989b). Effect of nitrogen and potassium fertilization on Hayany date palms in sandy soil.I. Growth, flowering, fruit set and retention. Egypt. J. Appl. Sci.,4(3), 416-424.

Snedecor, C.W. and W.G. Cochran (1990). Statistical methods $7^{\text {th }}$ ed. The Iowa State Univ. Press. Ames Iowa. USA. P. 593.

Shahein, A.H.; A.M. Attalla; H.A. Kassem and Hoda S.H. Aly (2003). Effect of applying different organic and inorganic nitrogen sources to Zaghloul and Samany date palm cultivars on I. Yield, fruit quality and fruit content of some pollutants. International Conference on Date Palm, Kingdom of Saudi Arabia. P: 195-207.

Sourour, M.M.; M.B. El-Sabrout and I.A. Mousa (1998). Effect of some sea weeds and mineral nitrogen fertilization treatments on growth, yield, fruit quality and nutritional status of "Samany" and "Hayany" date palms grown in North-Sinai. Egypt. J. Appl. Sci., 13(12):247261.

Swain, T. and W.E. Hillis (1959). The phenolic constituents of Prunus domestica. I. The quantitative analysis of phenolic constituents. J. Sci.Food Agric., 10: 63-68.

Tam, R.K. and O.C. Magistad (1935). Relationship between nitrogen fertilization and chlorophyll content in pineapple plants. Plant Physiol. 10 (1): 159-168.

Zaid, M.S. and H.M. Kriem (1992). Effectof sugar cane wastes and sulphur on some soil properties and nutrients uptake by Zea maize plants in sandy soil. J. Agric. Sci. Mansoura Univ. 17(1):181-188.

Zawadzka, T.; H. Mazur; K.M. Mazure and K. Strska (1990). Contents of metals in vegetables from different regions of Poland in the years 1986-1988. 1. Contents of lead, cadmium and mercury. Roczniki panstwowego Zakaduhigieny, 41, 111. 


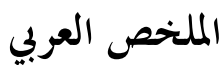

\section{تأثير إضافة مخلفات المدن كمصدر للنيتروجين سواء منفرداً أو مخلوطا بالنترات أو اليوريا على}

\section{صنفى نخيل البلح الزغلول والسمالن}

هدى سعد حسن على، محمد رجب محمد الشناوى، محمد أحمد فؤاد بدران التئي

وقد قل عحتوى الخوص من الكلوروفيل في كلا الصنفين وذلك

بإضافة خخلفات المدن وأن أعلى قيمة كانت في خوص النخيل المعاملة

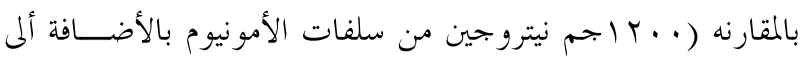

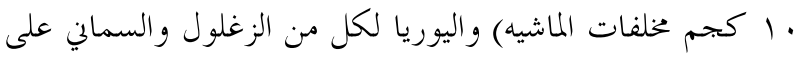

التوالي.

لم يتأثر محتوى الثمار والخوص من العناصر المعدنية ( نتروجين

والفوسفور والبوتاسيوم والمغنسيوم) بمعاملات التسميد المختلفة. بينما

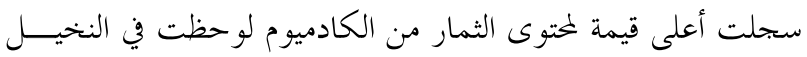

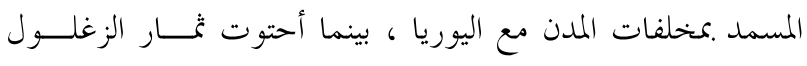

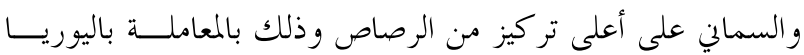

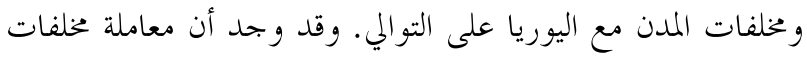

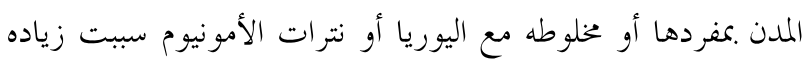
من الكادميوم في ثمار صنفى الزغلول والسمانى.

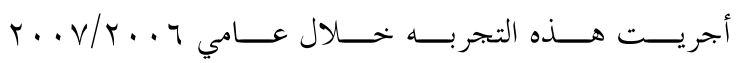

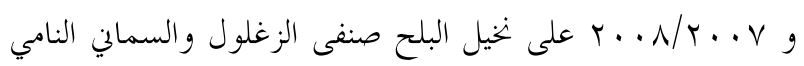

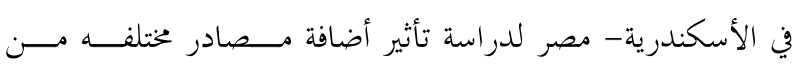

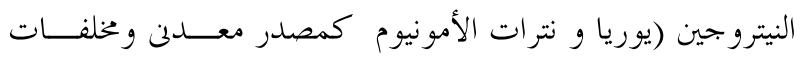

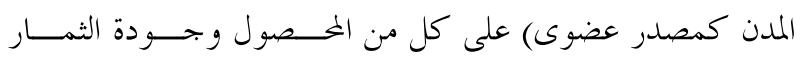

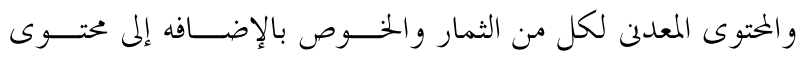
الخوص من الكلوروفيل. و كانت النتائج كما يلي: إضافة . . r ا جم نيتروجين صافن/نخله/سنه كتسميد لنخيل البلح

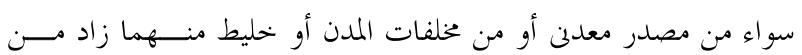

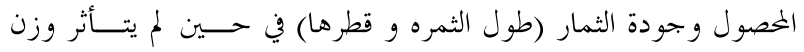

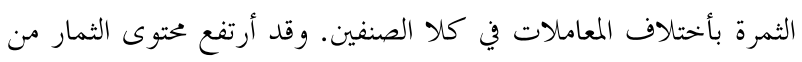

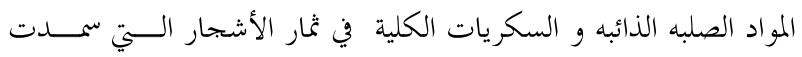
كمخلفات المدن المخلوط مع اليوريا لكل من صنفى الزغلول والسماند.

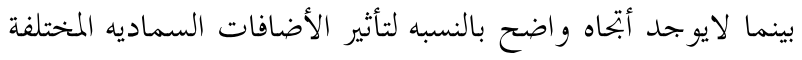
على محتوى الثمار من التانينات. 